\title{
The Sir Thomas Brisbane Planetarium and Amateur Astronomy in Queensland
}

\author{
Peter E. Anderson ${ }^{1}$ and Wayne Orchiston ${ }^{2,3}$
}

\begin{abstract}
Planetariums are a worldwide public educational, teaching and research phenomenon. In this paper, we very briefly examine their history in Australia, before focusing on the twentiethcentury development of amateur astronomy in Brisbane, the founding of the Sir Thomas Brisbane Planetarium in 1978, and the involvement of the South East Queensland astronomical community in this event. We also review the backgrounds and interests of the Planetarium's first two Curators, Jeff Ryder (1977-2002) and Mark Rigby (2002-2021), rank them as amateur astronomers when they joined the Planetarium, and present them as atypical examples of the amateur-turned-professional (ATP) syndrome in Australian astronomy.
\end{abstract}

Keywords: planetariums, Sir Thomas Brisbane Planetarium, amateur astronomy, Mark Rigby, Jeff Ryder, ATP syndrome

${ }^{1}$ Taylor Range Observatory, The Gap, QLD 4061, Australia (peteranderson53@bigpond.com)

${ }^{2}$ National Astronomical Research Institute of Thailand, 523 Moo 1, Soi Ban Cholae, Mae

Thaeng, Chiang Mai 50150, Thailand

${ }^{3}$ Centre for Astrophysics, University of Southern Queensland, Toowoomba, QLD 4350, Australia(wayne.orchiston@gmail.com)

Anderson, P. E., \& Orchiston, W. (2021). The Sir Thomas Brisbane Planetarium and amateur astronomy in Queensland. Proceedings of The Royal Society of Queensland, 129, x-xx. https:// doi.org/10.53060/prsq.2021.3

\section{Introduction}

A planetarium is a facility that contains a domed ceiling onto which a night sky can be projected for an audience below with either an opto-mechanical star projector and ancillary projectors; or with digital/video projector systems that enable fulldome video projections for recreating the night sky or, indeed, 'flying' through the Universe and using various data sets. Either system may be adjusted for viewing the sky at any time of night, from any part of the world, and can be set to show the night sky on a particular date (including in historical times). It also displays the position and movement of the Moon, planets, etc. Planetariums are excellent educational and teaching aids (Yu et al., 2017; Plummer \& Small, 2018; Creighton \& DeVasto,
2019; Daut, 2020), and they occasionally are used also for archaeoastronomical, ethnoastronomical or historical research (Vahia \& Halkare, 2013).

In August 1923, the first planetarium projector was set up in a dome on top of the Zeiss factory in Jena, Germany, for the world's first unofficial presentations. It was installed for its first official demonstration at a congress in Munich's Deutsches Museum on 23 October 1923. It was returned to Zeiss for finishing touches before being permanently installed back in Munich during May 1925 (see King \& Millburn, 1978). The Adler Planetarium opened in Chicago, USA, in 1930, and increasing numbers of planetariums appeared throughout the nation over the next 40 years (Marché, 2005). Planetariums are now a worldwide

This work is licensed under a Creative Commons Attribution-NonCommercial-NoDerivatives 4.0 International Licence. Individual articles may be copied or downloaded for private, scholarly and not-for-profit use. Quotations may be extracted provided that the author and The Royal Society of Queensland are acknowledged. Queries regarding republication of papers, or parts of papers such as figures and photographs, should be addressed to the Secretary of The Royal Society of Queensland (rsocqld@gmail.com). 
phenomenon (see the International Planetarium Society: https://www.ips-planetarium.org).

Australia gained its first planetarium in 1950 (Jacob, 2010; Anon., 1950), when a Spitz projector was installed under a small (14 ft diameter) dome at the Museum of Applied Arts and Sciences in Sydney (Figure 1). After a hiatus of 15 years, planetariums emerged in rapid succession in Australia, first at the Science Museum of Victoria in Melbourne in 1965 (Cavill, 1968; Hirst, 2002) and then at the Queen Victoria Museum and Art Gallery in Launceston, Tasmania, in January 1968 (George, 2021). It was followed in 1972 by one that was used as a teaching aid, mainly for surveying students, at what was then the Levels Campus of the South Australian Institute of Technology in Adelaide. Queensland's first planetarium, the Sir Thomas Brisbane Planetarium, opened in the Brisbane Botanic Gardens, Mt Coot-tha, in 1978.

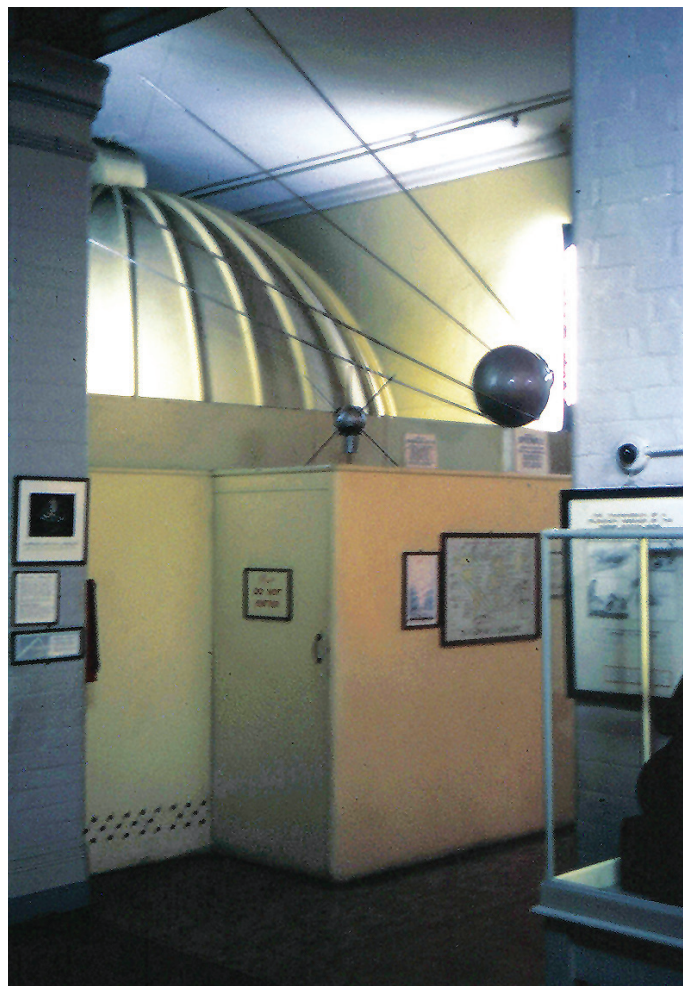

FIGURE 1. The small planetarium established in 1950 at Sydney's Museum of Applied Arts and Sciences in Harris Street, Ultimo (Photo: Peter Anderson, 25 September 1963).
In 2021 there are six long-established Australian planetariums with fixed, solid domes with diameters of 8 metres or more that are institutional members of the Australasian Planetarium Society. There are others either planned or soon to open, as well as numerous portable/inflatable planetarium domes that are either located permanently at a facility or transported to and set up at locations such as schools (Martin George, pers. comm., June 2021). We are reminded by Wollongong planetarium guru, Glen Moore (2020, p. 13), that a notable feature of the Brisbane Planetarium is its stand-alone status: "Coupling a planetarium with a science centre can be a winning strategy. Every major planetarium in Australia apart from the Sir Thomas Brisbane Planetarium, is associated with a science centre." In this paper we explore events leading up to the founding of the Sir Thomas Brisbane Planetarium, and the role that Brisbane amateur astronomers played in this process and in the subsequent history of the Planetarium.

\section{The Development of Astronomy in Queensland}

Although Indigenous astronomy has a history extending back tens of thousands of years in what is now the state of Queensland (Fuller et al., 2014a, 2014b, 2014c; Norris, 2016), Western astronomy only arrived with the first explorers, surveyors and settlers, beginning with the charting of the coastline in 1770 by James Cook (1728-1779) and Charles Green (1734-1771), the astronomers on the barque Endeavour (Beaglehole, 1963, 1968). Lieutenant Cook also commanded the vessel and led the expedition (Beaglehole, 1974), and by the time he was slain in Hawaii on 14 February 1779, at only 50 years of age, he had become ".. a colossus of British discovery, exploration, hydrographic surveying and nautical astronomy" (Orchiston, 2016, p. 191).

As in other colonies, active astronomers were rare in Queensland during the first half of the nineteenth century. In 1859, Queensland separated from New South Wales and became a stand-alone colony, but unlike the other Australian colonies, the government in Brisbane never saw fit to establish a professional observatory (Haynes et al., 1996). What they did commit to, however, was the provision of a local time service, and commencing on 
14 October 1861 a 'time ball' was dropped daily at $1.00 \mathrm{pm}$ from a mast on the top of the old windmill building on Wickham Terrace (Anderson, 2019). On 18 June 1866, this was replaced by a $1.00 \mathrm{pm}$ time gun fired from the same site. The sound of the firing gun could be heard far beyond the visual confines of the old windmill.

Prominent amateur astronomer ${ }^{\mathrm{a}}$ Captain Henry O'Reilly (1824-1877) (Anderson, 2020) had developed a considerable reputation for keeping his own accurate time and regulating marine chronometers, although there is no indication that he participated in the official time service.

After O'Reilly's death in 1877, the government purchased his observatory and associated instrumentation and set up the Brisbane Observatory on Wickham Terrace in 1881, where an 'Astronomical Observer' employed by the Survey Department made regular observations with the transit telescope and provided a local time service (Haynes et al., 1993). But the Brisbane Observatory was a modest wooden building, and it quickly became dilapidated and had to be closed in 1919. An impressive-looking new Queensland Observatory was planned and foundations were even laid, but the project was abandoned due to costs. Subsequently, timekeeping was conducted from a hut with a transit telescope erected atop a city building - the cost of this arrangement was one-tenth of the cost of the new dedicated observatory.

In Queensland towns outside Brisbane, timekeeping and/or meteorology occasionally were the domain of amateur astronomers, such as Townsville's Charles Sydney Norris (1859-1935) (Orchiston \& Darlington, 2017). Some of these amateur astronomers also attempted to contribute to non-meridian observational astronomy. For example, J. Ewen Davidson (1841-1924) (Orchiston \& Darlington, 2017), a 'sugar baron' from Branscombe, near Mackay, discovered new comets and made observations of known ones. In the process he was able to acquire international visibility, no mean feat for an amateur scientist from the Antipodes. Other Queensland amateur astronomers living in the countryside, such as Irvinebank's Dr William McFarlane (1866-1919) (Orchiston,
1985), saw their brief as providing astronomical education and outreach for local residents, and especially schoolchildren. At a national level, amateurs collectively made a major contribution to the astronomical education of the Australian public (Orchiston, 1998), and their work should be viewed as complementary to that of the professional astronomers in the colonial and state observatories (Orchiston, 1991).

Orchiston $(1998,2017)$ has documented how, following earlier abortive attempts in the 1870 s and 1880 s, the time was ripe by the 1890 s for the establishment within Australia of astronomical societies, and these were formed in Adelaide in 1892, Sydney in 1895, Brisbane in 1896 and Melbourne in 1897. But whereas those in the southern colonies could boast close amateur-professional relations and amateur astronomers with international reputations who could serve as ideal role models, in Brisbane there was neither. Moreover, the Brisbane Astronomical Society (BAS) was formed primarily to prevent a 6-inch refracting telescope that was put up for sale from transferring interstate, rather than to encourage and foster amateur astronomy and promote serious observing projects. Elsewhere (Anderson \& Orchiston, 2020), we have traced the history and inevitable demise of the BAS in 1917, which also was marked by conflict and competition between two leading Brisbane astronomers, Dudley Eglinton (1850-1937) and James Park Thomson (1854-1941). Thus, personalities and politics helped stifle Brisbane's first attempt to formalise amateur astronomy in the state's capital city.

After the demise of the BAS, Eglinton formed the Queensland Popular Science and Art Society in 1919, which had a wider remit than the BAS in that its portfolio was not restricted to astronomy. Nonetheless, the Society acquired a fine 12-inch reflecting telescope from a Sydney amateur astronomer in order to promote observational astronomy among members with such interests. Sadly, Eglinton became blind soon after the telescope was operational, and without his leadership the Society quickly became defunct (Anderson \& Orchiston, 2020).

Not long after, the body that was soon to be titled 'The Astronomical Society of Queensland' (ASQ) held its inaugural meeting on 3 October

\footnotetext{
a For the purposes of this paper, an 'amateur astronomer' is defined as someone involved in astronomy for the love of it, and who normally does not derive a primary income from astronomy (Orchiston, 2015).
} 
1927, with Dudley Eglinton becoming one of the Vice-Presidents. Thomson is not recorded in any prominent role. Although blind and in his 70s, Eglinton continued to write papers that his wife delivered on his behalf. He also managed to transfer the funds of the old Brisbane Astronomical Society to the new Society. In 1935, Eglinton was made an honorary life member of the Society. He died two years later in 1937.

Later, from 1942, the driving forces in this long-running Society were William (Bill) Newell (1912-1971) and his wife 'Molly'. Bill Newell was the Queensland Government's 'Astronomical Observer' and was responsible for maintaining Brisbane's time service between 1947 and 1957. As Secretary from 1942 until his death in 1971, Bill Newell oversaw the affairs of the Society, and his policy of encouraging armchair ${ }^{\mathrm{b}}$ amateur astronomy rather than just observational astronomy increasingly irritated some of the more active members:

It is the duty of the Society ... to suit the general interest of members, an interest though serious and studious still being primarily of a recreational nature ... The aspects of astronomical interest are most varied and observing is only one phase of astronomical interest (Newell, 1969, p. 57).

As detailed later, they eventually broke away and formed the Astronomers' Association, Queensland (AAQ) in 1969. Both organisations catered for Brisbane's growing amateur astronomy fraternity until 1978 when they amalgamated. By this time, the vigour had gone from the earlier arguments, and the chief protagonists had mellowed or passed on. Consequently, the amalgamation vote was unanimous, and the new combined organisation was called the Astronomical Association of Queensland. Thus, the acronym AAQ continued in use, but readers should be aware that post-March 1978 this describes the newly merged organisation.

The merger occurred about the same time that the Sir Thomas Brisbane Planetarium opened, and the respective involvement of the two earlier societies in events leading up to the founding of the planetarium is outlined below.

\section{Events Leading Up to the Construction of the Sir Thomas Brisbane Planetarium}

The retiring Curator of the Sir Thomas Brisbane Planetarium, Mark Rigby, advises (pers. comm., March 2021) that to his knowledge the first documented attempt to establish a planetarium in Brisbane was in 1954 when a group of Brisbane businessmen estimated the cost of the facility to be $£ 100,000$. They had been in contact with the agency of the Zeiss Optical company in Australia. It was also suggested that it might be named after Inigo Owen Jones (1872-1954), the long-range weather forecaster who had just died (Anon., 1954). Three possible sites were suggested: the Botanic Gardens in Brisbane city, Mt Coot-tha, or the grounds of Queensland University (St Lucia, Brisbane). This concept, comparable in scale to the later Sir Thomas Brisbane Planetarium, was floated without detailed designs or costing in an attempt to attract official support through the cooperation of either the State or the Federal Government. This was not forthcoming, and little more was heard of the idea.

The next occasion for consideration of a planetarium and supporting infrastructure came to the fore as the result of a visit by West German Zeiss representatives in 1966. The initial approach had been through the Museum Society. However, given the nature of the proposal, the Astronomical Society of Queensland (ASQ) soon became involved. The proposal, subsequently championed by the ASQ, was for:

(1) an observatory to house the venerable 12inch reflector previously mentioned that had come into the Society's possession and was then on temporary loan;

(2) a building to hold meetings/lectures, etc.; and

(3) if feasible, a planetarium provided that appropriate support was forthcoming. This was a real possibility given the interest of the Brisbane City Council following the Zeiss visit.

The Brisbane City Council offered two potential sites that a group of ASQ members inspected in August 1966. These were atop adjacent knolls at Mt Coot-tha on a spur approached by a short gravel road, now called the Honeyeater Track, some $400 \mathrm{~m}$ further on from the Lookout. The image

b 'Armchair' is used here as a purely descriptive term and does not imply any derogatory connotations. 
of the inspection party taken at the time is telling (Figure 2). The architect Fred Lafferty, who had recently joined the Society, his son Lee, and Arthur Page are in discussion with Bill Newell at the left of the image. As the lead author of this paper observed from first-hand experience, tensions had already been building and the go-slow attitude of the Newells was frustrating many.

The situation was complex but finally came to a tipping point over the refusal to establish a finance committee for the project and start serious fundraising. In fact, only a few hundred dollars were ever subscribed, and the $25 \times 75 \mathrm{ft}(7.6 \times 22.9 \mathrm{~m})$ meeting building alone was estimated to cost around $\$ 10,000$. Dissatisfaction festered, and the dissatisfied members slowly withdrew from participation in the affairs of the ASQ.

Quite possibly using the constitution of the recently established professional body, the Astronomical Society of Australia (Lomb, 2015) as a model, a new body known as the Astronomers' Association, Queensland (AAQ) was formed on 8 February 1969. Any further serious interest in the project within the ASQ soon fizzled out. Later, after the Planetarium had been established for some years, key optical parts from the historic 12-inch reflector that were in storage were donated, and occasionally these are on display at the Planetarium.

With more than 60 years' experience in local astronomical societies, the first author of this paper can understand the Newells' reluctance to get involved in a major project such as the construction and maintenance of the meeting building, observatory, and possible planetarium. It may well have been a hard-headed realisation and realistic assessment and knowledge of the demographics and capabilities of the general membership (Newell, 1966). After its formation in 1969, the AAQ focused on observational matters and did not become involved in any further such projects. However, this same story was to be repeated a number of times - for example, there was another such detailed proposal in 1983 for a Mt Coot-tha observatory and meeting site, and the later leasing of the Morningside clubhouse (19962001). A project, large or small, was enthusiastically supported and approved by AAQ members, but the actual work was left to a few volunteers, so projects either foundered or produced very meagre results.

In any event, after the late 1960s, John O'Hagan of the Museum Society continued to promote the planetarium concept with some support from the ASQ and AAQ. He even proposed the name. However, the eventual detailed planning and construction were entirely Brisbane City Council initiatives and succeeded brilliantly, with contracts being issued for the detailed design in early 1976, construction taking place from early 1977 and completion in 1978.

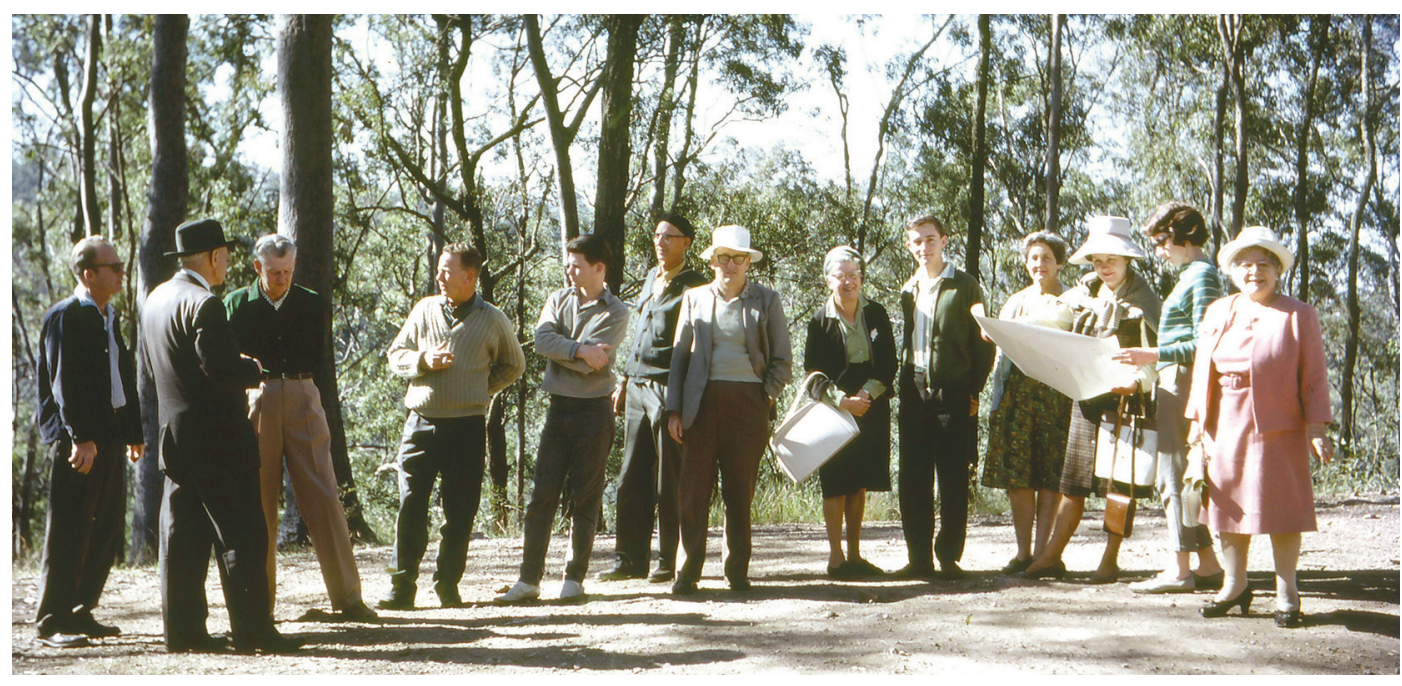

FIGURE 2. Members of the Astronomical Society of Queensland inspect a proposed observatory/meeting rooms/ planetarium site at Mt Coot-tha on 27 August 1966 (Photo: Peter Anderson). 


\section{The Sir Thomas Brisbane Planetarium}

The Sir Thomas Brisbane Planetarium is built at the base of Mt Coot-tha, Brisbane, on its eastern, city side. The Mt Coot-tha botanical gardens largely surround it to the south. It was named after the Scot Sir Thomas Brisbane (1773-1860) (Figure 3), who was the Governor of the New South Wales colony between 1821 and 1825 and who also gave his name to the settlement of Brisbane, which was founded in 1824. Sir Thomas was a keen astronomer, and at his own expense he erected and equipped a private observatory close to his residence, Government House, in Parramatta (about $21 \mathrm{~km}$ west of Sydney Cove), where he employed a trained astronomer, Charles Rümker (1788-1862) from Germany, and a Scottish technical assistant named James Dunlop (1793-1848) (Lomb, 2004). The staff at Parramatta Observatory (along with Sir Thomas Brisbane) were very actively involved in observational astronomy (Saunders, 2004; Letchford et al., 2017), and apart from the discovery of comets, the Observatory is best known for its catalogue of southern stars (Richardson, 1835). Given the astronomical focus of Brisbane's new planetarium, it is particularly appropriate that it was named after Sir Thomas Brisbane.

The Sir Thomas Brisbane Planetarium was built and is operated by the Brisbane City Council. The instigator of the project within Brisbane City Council was the long-term (1961-1975) and highly respected Lord Mayor, Clem Jones (1918-2007). On 28 December 1973 he unveiled a plaque atop Mt Coot-tha (Figure 4), but upon the decision to co-locate with the Brisbane Botanic Gardens on Mt Coot-tha (opened in 1970), the Planetarium was instead constructed adjacent to the Gardens' entrance.

The Planetarium, with its original East German Zeiss projector, was officially opened by Lord Mayor Frank Sleeman (1915-2000) on 24 May 1978 (Ryder, 1979), as shown in Figure 5. It is a substantial building (Figure 6) that includes a domed observatory, a small lecture theatre, a foyer, and an exhibition area with a circular display gallery around the 130 -seat main theatre (originally there were 144 seats). This theatre is topped by the 12.5-metre projection dome (an improved one was installed in 2013).

The original projector continued in use until
2010 and was later installed for display in the foyer (Figure 7). Its use overlapped with a digital system with eight CRT projectors installed in 2004. While sacrificing some projected star image quality, this upgrade provided freedom for computerised simulations. Further major upgrades were made, the latest completed in May 2019 with a new digital system installed and with a resolution of nearly $7 \mathrm{~K}$ (7,000 pixels) across the dome. Regular upgrades and maintenance occur as appropriate.

Although over the years the Sir Thomas Brisbane Planetarium has made a major contribution to the astronomical education and entertainment of Queenslanders and visitors to Brisbane (Axam et al., 2006; Ryder, 1984), its survival was not always guaranteed. In 2001, after a period of operational and financial tightening, the Soorley administration of the Brisbane City Council considered the possible closure of the Planetarium.

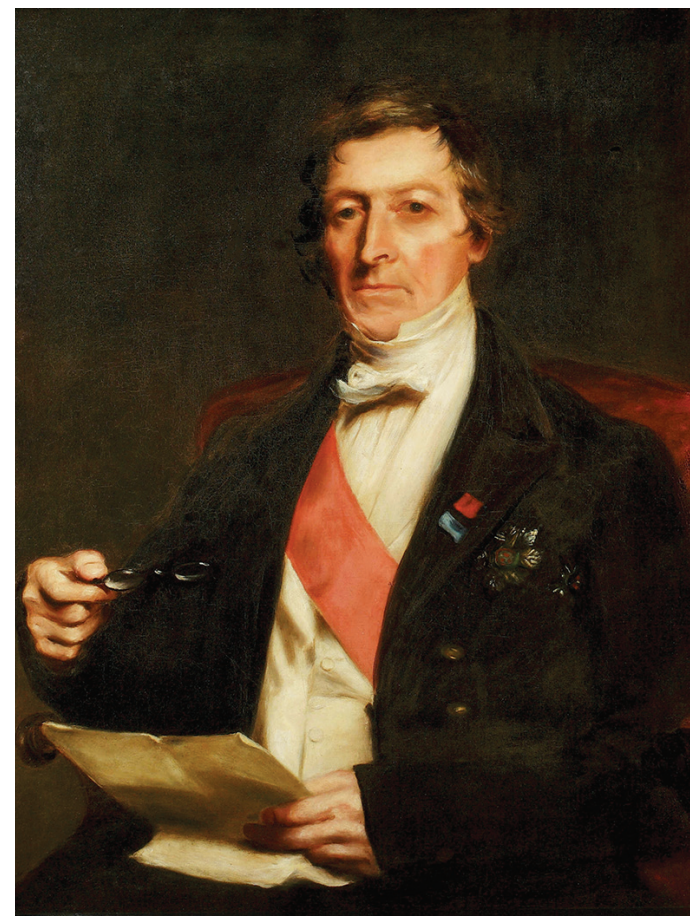

FIGURE 3: General Sir Thomas Makdougall Brisbane, 1894 by Jessie Drummond after John Watson-Gordon (1788-1864), oil on canvas - gift of the Town Council of Largs, Scotland, 1954, City of Brisbane Collection, Museum of Brisbane. 


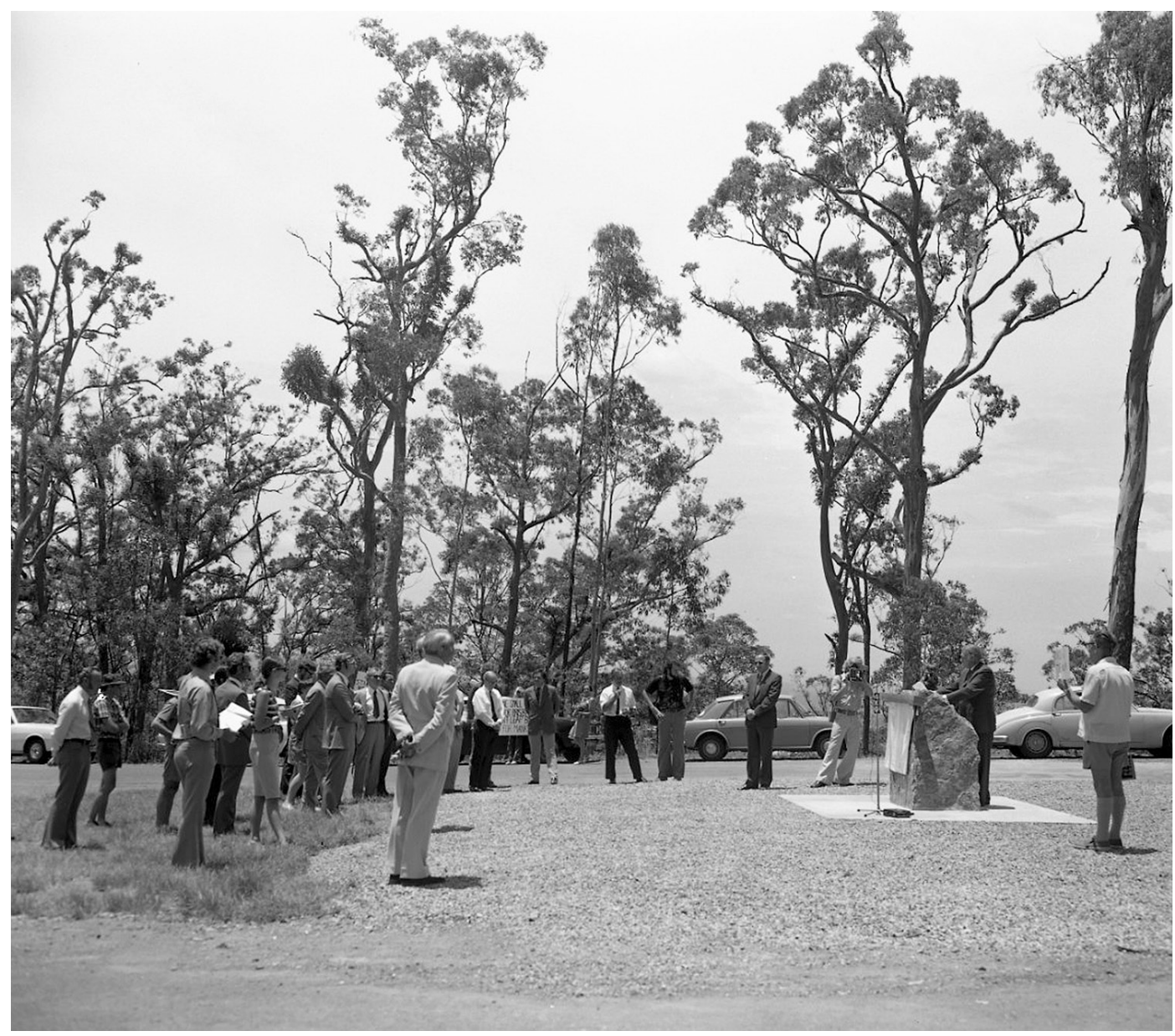

FIGURE 4. Brisbane Mayor Clem Jones unveiling the plaque at the site of the proposed planetarium atop Mt Coot-tha on 28 December 1973 (C Brisbane Images, courtesy of Brisbane City Council).

However, a case was made that planetariums should be compared with museums, libraries, and even parks. The Sir Thomas Brisbane Planetarium provided a scientific and educational service to the community, and although funded by a council or government, it could not be expected to provide a surplus. At best, ticket sales might cover day-to-day expenses and wages. Therefore, the Planetarium should be treated as a cultural asset, not as an unsuccessful commercial venture that should be discarded.

There was considerable public objection to the possibility of closure, including a public protest outside the Planetarium in May 2001 that drew extensive media attention. Former Lord Mayor
Clem Jones expressed his concern, and famous British astronomer Sir Patrick Moore (1923-2012) also came out in support of Brisbane's planetarium (Mobberley, 2015). This was at a time when Jeff Ryder was heading into planned retirement. Uncertainly surrounded the future of the Planetarium for two years before the Brisbane City Council, under the administration of Lord Mayor Tim Quinn, made the commitment in September 2003 to upgrade the facility. Since then, the Planetarium has remained open, and apart from short closures for maintenance and upgrades, and the recent COVID-19 lockdown, it has operated continuously as a unique Brisbane educational attraction since 1978. 
Peter E. Anderson And Wayne Orchiston

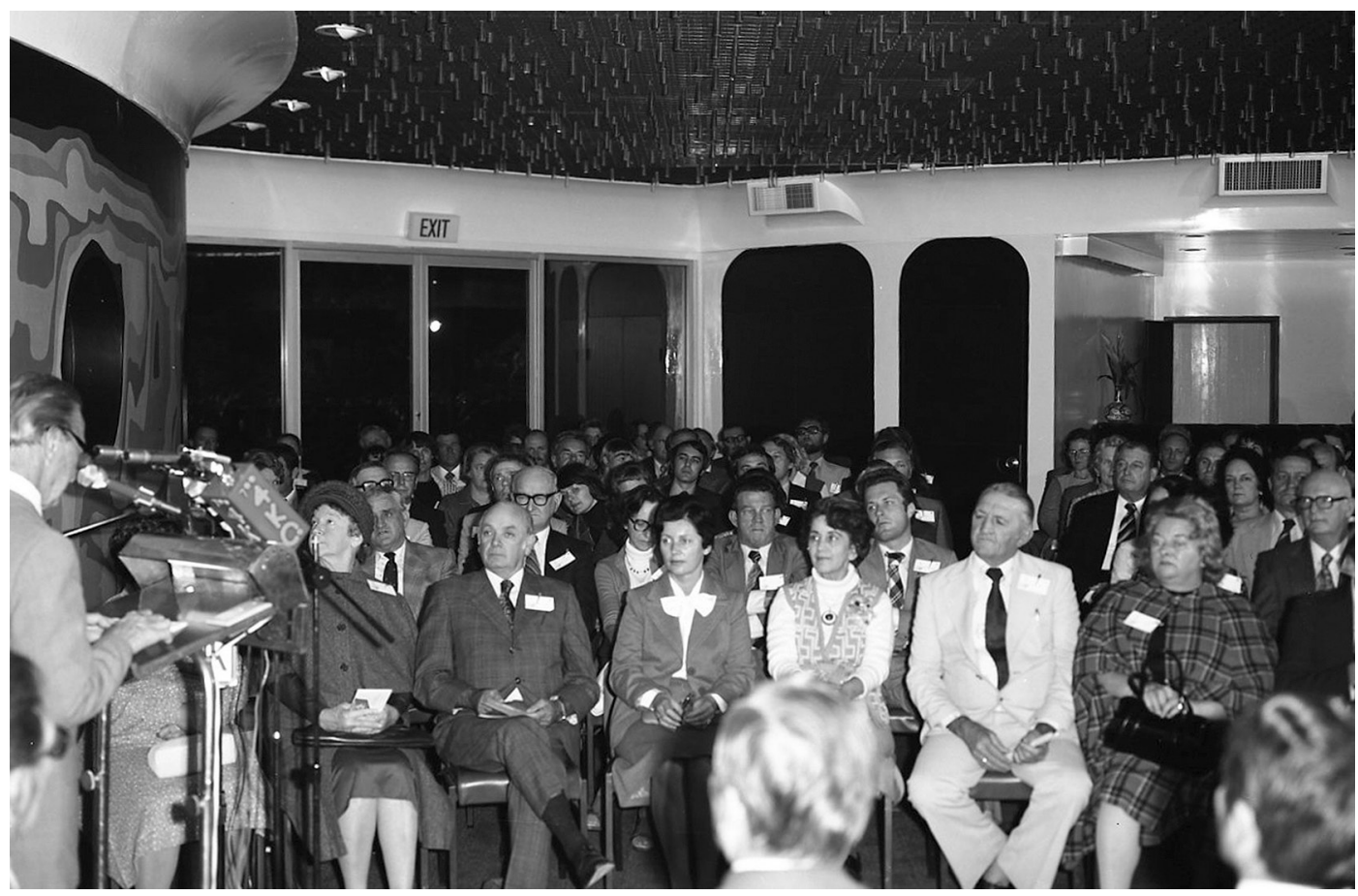

FIGURE 5. The opening of the Sir Thomas Brisbane Planetarium on 24 May 1978 (C) Brisbane Images, courtesy of Brisbane City Council).

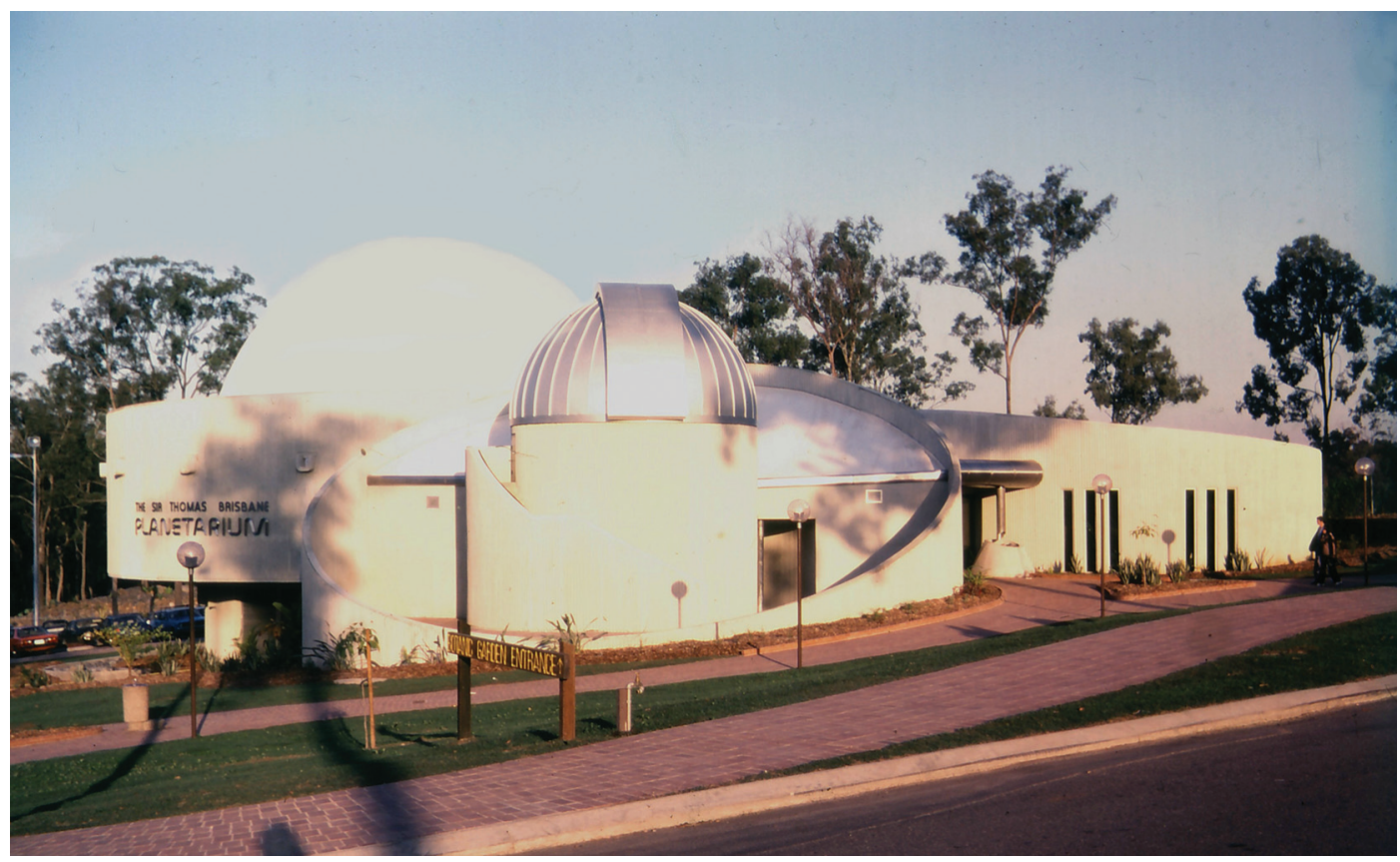

FIGURE 6. The Sir Thomas Brisbane Planetarium in June 1978 (Photo: Peter Anderson). 


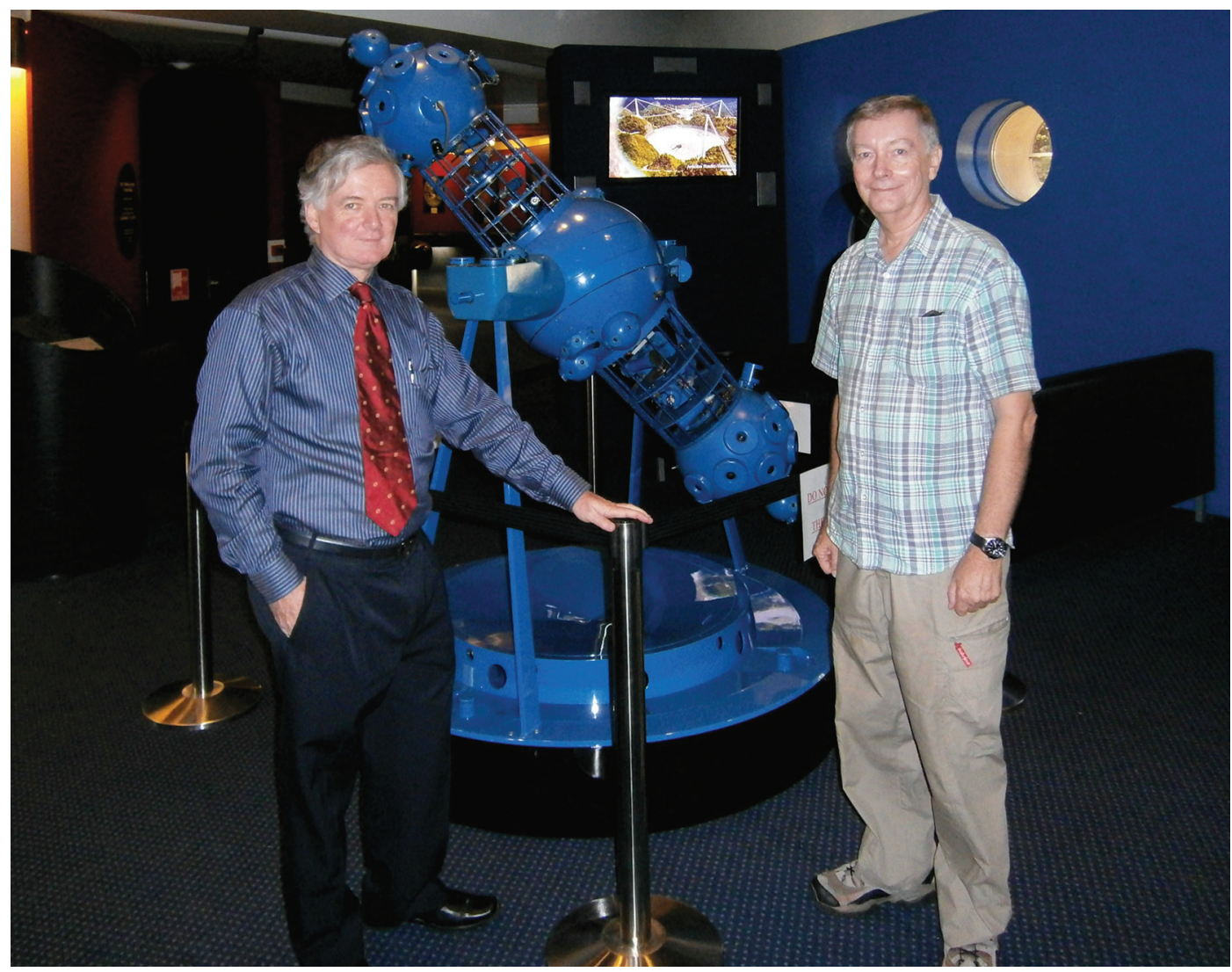

FIGURE 7. Mark Rigby and Jeff Ryder with the retired Zeiss projector on display in the foyer in 2012 (Photo courtesy of Mark Rigby).

\section{Amateur Astronomy and the First Two Curators}

The founding Curator of the Sir Thomas Brisbane Planetarium in 1978 was Jeff Ryder, who retired in 2002. He was succeeded by Mark Rigby, who continued until the end of February 2021, when he went on long service leave pending his retirement in August 2021 at age 67. Mark had joined Jeff Ryder as Assistant Curator in 1985, and his 36 years of service make him the longest-serving staff member of the Planetarium. The position of 'Curator' has now been discontinued, replaced by the position of 'Planetarium Venue Manager' that was advertised in February 2021.

\section{The Inaugural Curator, Jeff Ryder}

Jeff Ryder (b. 1947) had first joined the Astronomical Society of Queensland (ASQ) as a teenager in 1961.
On 9 March 1962, the 14-year-old gave a presentation at a General Meeting of the Society, detailing his lunar observations and the history of lunar observation. Later that year, he arranged a Society observing night held on 6 October 1962 at Brisbane Boys' College in Toowong. He contributed to the Society's journal - for example, with an article on lunar observations in the December 1967/January 1968 edition. With two other speakers, he gave the address at the April 1969 meeting of the Society. In July 1969, he succeeded the first author of this paper as the Society's Observing Officer. Between late 1969 and mid-1971, he occupied the positions of Observing Officer and Assistant Secretary.

The Astronomers' Association, Queensland (AAQ) had been formed on 8 February 1969, and until 1978 both organisations ran in parallel, sharing a number of members. The AAQ was a very active 
and observationally oriented body, whereas the ASQ concentrated more on members with an 'armchair' interest in astronomy. After joining the AAQ in 1971, Jeff Ryder was elected to full membership in 1972 and became very active in AAQ affairs. In 1972-1973 and 1973-1974 he was General Secretary of the AAQ, and a Councillor in 1974-1975 and 1976-1977. In 1977-1978 he was Vice President and continued in this position until shortly after the amalgamation. In addition, between 1975 and 1978 he was Director of the observing section devoted to lunar observations, including lunar transient phenomena, employing coloured filters to detect possible anomalous transient glows.

Over the years, Jeff Ryder became an experienced astronomical observer, but as with many young amateurs at this time who had a deep commitment to observational astronomy but shallow pockets, he started with a modest $50 \mathrm{~mm}$ refractor. As means allowed, he progressed to a $152 \mathrm{~mm}$ reflector, and by the mid-1970s had a $254 \mathrm{~mm}$ reflector, plus a $102 \mathrm{~mm}$ refractor as a portable instrument (Figure 8).

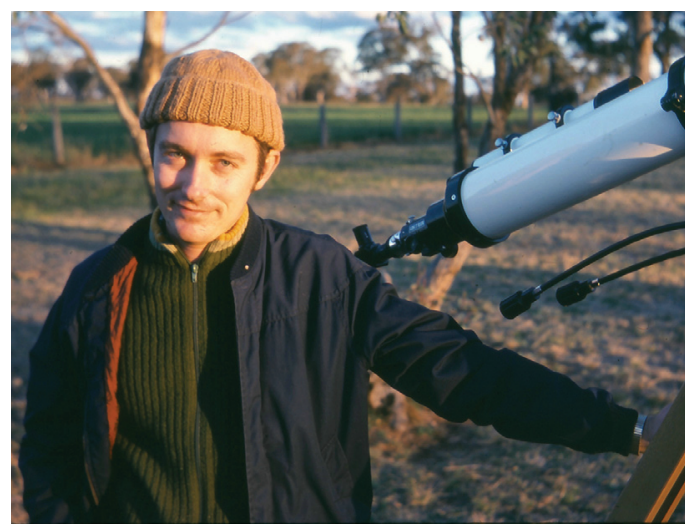

FIGURE 8. Jeff Ryder with his 4-inch refractor at Murray Bridge State School in 1976 (Photo: Peter Anderson).

Prior to his appointment on 4 July 1977 as the founding Curator of the new Sir Thomas Brisbane Planetarium (then under construction), Jeff Ryder worked for the City Insurance Company. After moving to the Planetarium, he considered it appropriate to place himself at arms' length from direct astronomical society participation, although he was a member of the amalgamated society in
1978 when the AAQ and the ASQ merged, and remained so until 1993. Through his position at the Planetarium, Jeff was able to travel widely, and he endeavoured to keep up to date with various aspects of astronomical research.

\section{The Second Curator, Mark Rigby}

Mark Rigby (b. 1954) first attended ASQ meetings in early 1967 and joined the Society in 1968. He was the ASQ Planetary Section Director from July 1973, a title later changed to the Lunar and Planetary Section. For his observations, he made use of a $152 \mathrm{~mm}$ reflecting telescope that he had built. In 1978 he became a member of the newly merged organisation (the AAQ) as a full member and Councillor. By the end of December 1979, he was Technical Secretary and Editor, and retained these positions in 1980 and 1981. In 1982 he continued as Editor, and in 1983 and 1984 he was President. He remained a member until 1988. His close contact with the AAQ came to an end when he became Assistant Curator at the Planetarium in 1985.

By the time he joined the Planetarium staff, Mark Rigby was an experienced science writer and astronomy educator. From the 1970s he wrote on space activities for the Brisbane Courier-Mail, prepared other publications, and produced 'teacher kits' and student material on subjects ranging from space exploration to ancient civilisations. He also had a deep knowledge of space exploration missions and travelled widely to pursue this interest. Thus, over the decades he visited many US and Russian space facilities and was at the Baikonur Cosmodrome in Kazakhstan for the launch of a Soyuz crew to the International Space Station. In 1975 he met Wernher von Braun, the famous German rocket scientist (Figure 9), and years later stumbled through the ruins of the $\mathrm{V}-2$ rocket development and production sites in Germany. In more recent years, his extensive travel included observing total solar eclipses in various parts of the world. Since going on leave pending retirement in August 2021, Mark has served as an astronomy commentator on two chartered Qantas Dreamliner flights south of Australia to observe auroras. All these interests and activities were certainly relevant to his employment at the Planetarium. 


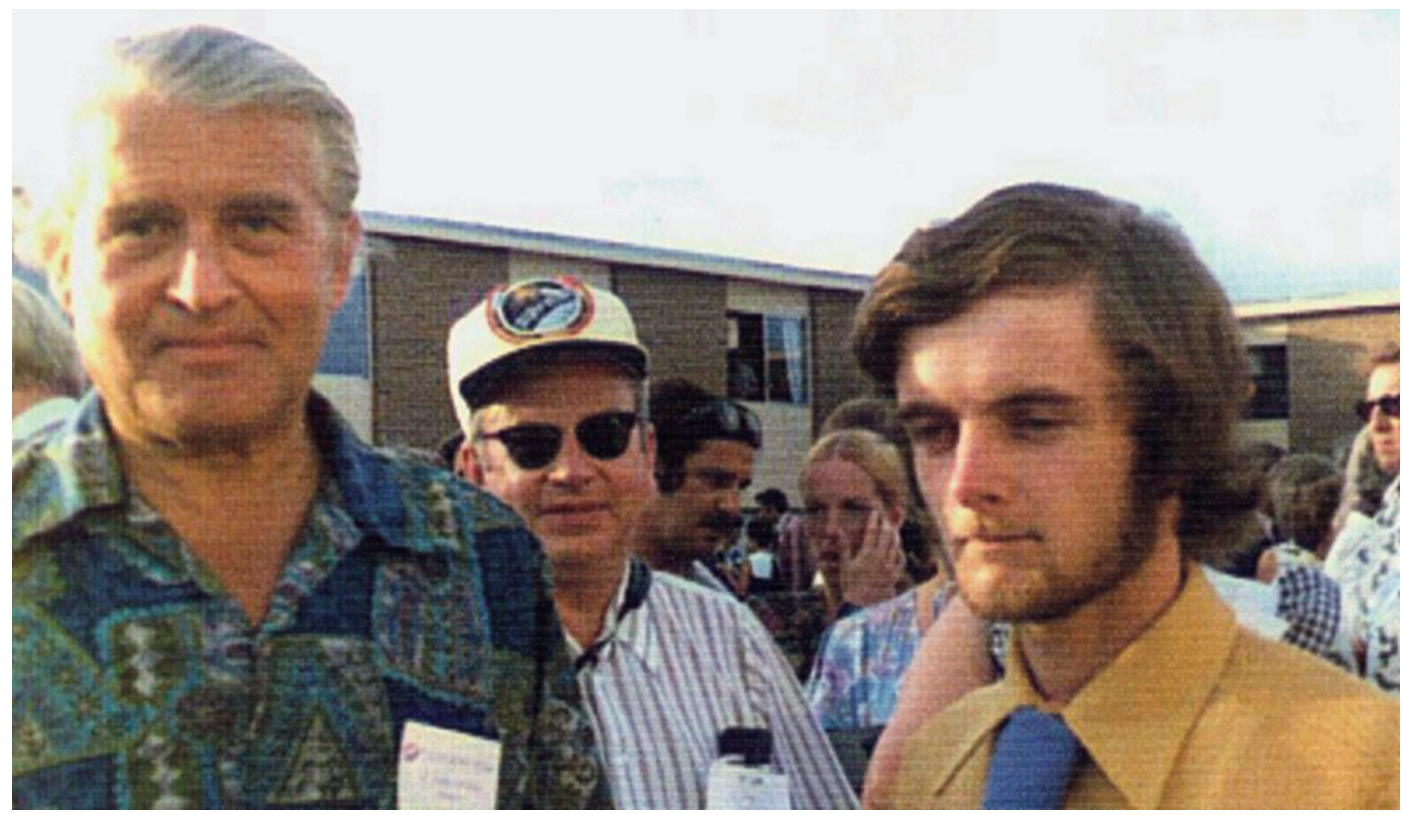

FIGURE 9. Wernher von Braun and Mark Rigby in July 1975 (Photo courtesy of Mark Rigby).

Obviously, his position as Curator at the Planetarium also entailed travel to attend conferences (usually self-funded). He was a long-term Treasurer of the Australasian Planetarium Society from 2003 to 2019, except while serving as its President from 2008 to 2012, and he has represented the region at meetings of the International Planetarium Society.

Finally, Mark also has a particular interest in Sir Thomas Brisbane, who was known also for establishing Parramatta Observatory near Sydney. During his lifetime, Sir Thomas also established observatories on his estates in his native Scotland (e.g. see Morrison-Low, 2004). In 2018, Mark accepted the position of Honorary Vice President of the Brisbane Observatory Trust in Scotland.

\section{Classifying and Ranking Amateur Astronomers}

How should we classify and rank Jeff Ryder and Mark Rigby as amateur astronomers when they joined the staff of the Sir Thomas Brisbane Planetarium in 1977 and 1985, respectively?

The US astronomer Dr Tom Williams (2000) has analysed American amateur astronomers, and he distinguishes between those who actively contributed to science and those who engaged in astronomy for recreational purposes only. When they joined the staff of the Sir Thomas Brisbane Planetarium, both Ryder and Rigby were 'active' rather than 'armchair' amateur astronomers.

Since the late 1970s, the Canadian Professor of Sociology and amateur astronomer Robert A. Stebbins has pioneered a whole new field of research, the sociology of 'amateurs' (e.g. Stebbins 1977, 1978, 1979, 1980a, 1992). In the context of this paper, amateurs straddle the nebulous boundary between work and leisure and are 'amators', a melding of the words 'amour' and 'amateur', in the strict sense in that they love their hobby and are happy to invest time, money and effort in it for the sake of the expected 'rewards' (Williams, 2000). Five of Stebbins's later papers (1980b, 1981, 1982a, 1982b, 1987) deal specifically with avocational astronomy, and these form an important contribution to our discipline.

Using 'dedication' as a criterion, Stebbins distinguishes 'devotees' from 'dabblers', and before they came to the Planetarium, both Rigby and Ryder were clearly 'devotees' - individuals who were happy to make a substantial commitment to the science in terms of both time and money. Using another dimension, 'knowledge and involvement', Stebbins differentiates between 'active' and 
'armchair' astronomers, just as Williams (2000) does. However, Stebbins also seeks to categorise individual active astronomers within an apprenticejourneyman-master continuum. Apprentices were beginning their astronomical 'careers', while masters were the acknowledged experts who were making a meaningful contribution to science whatever their area(s) of astronomical involvement. Jeff Ryder and Mark Rigby were both active amateur astronomers who in an Australian context sat at the 'master' end of the continuum. Therefore, at a local level they were accomplished, highly regarded amateur astronomers, even if they lacked formal academic qualifications in astronomy, or even undergraduate degrees, that usually were demanded of candidates seeking professional positions in astronomy.

\section{Jeff Ryder, Mark Rigby, and the Amateur- Turned-Professional Syndrome in Australian Astronomy}

During the nineteenth century, before the advent of 'giant' telescopes and the emergence of astrophysics, most observational astronomers were committed to positional astronomy, which focused on the positions of stars, planets, comets and other objects, and on the appearance, particularly the changing appearance, of the Sun, comets and particular planets. There was also strong interest in discovering and measuring double stars, and discovering and measuring the changing magnitudes of variable stars. In this environment, there was little difference between the intellectual prowess and astronomical achievements of professional astronomers and the world's leading amateurs: they conducted the same types of research using similar telescopes, belonged to (and in some cases led) the same astronomical societies, received the same medals and awards, and published in the same journals. In this environment, amateur astronomers were able to make important contributions to astronomical science (e.g. Dunlop \& Gerbaldi, 1988), and it was possible for leading amateur astronomers to make the transition to professional ranks. This is termed the amateur-turned-professional (ATP) syndrome.

This idyllic situation changed rapidly in the late nineteenth century when amateur and professional astronomers realised that they could apply photography, spectroscopy and photometry to astronomy, and study the composition, dynamics and evolution of the Sun, stars, gaseous nebulae and what later became known as galaxies (Clerke, 1903; Langley, 1884). As a result, “... astronomy underwent an observational, experimental and theoretical revolution as the long-entrenched classical (positional) astronomy was replaced by the 'new astronomy' known as astrophysics ... [which] focussed on patterns, processes and mechanisms; with changes through time; and with interrelations. It was largely non-descriptive, and emphasized the dynamic rather than the static" (Nakamura \& Orchiston, 2017, pp. 1-2). As professional astronomers underwent formal academic training in astronomy and gained access to ever-larger refracting and reflecting telescopes, amateur-professional relations began to sour (see Hetherington, 1976; Lankford, 1981a,b, 1979; Orchiston, 1999), and by the mid-twentieth century it was rare for amateur astronomers to conduct cutting-edge research and publish their results in professional astronomical journals. It also was challenging for all but the most accomplished amateurs to make the transition to professional ranks.

To some extent Australia mimicked international trends, but only after World War II with the development of galactic and extra-galactic astronomy at Mt Stromlo Observatory, and the phenomenal growth of radio astronomy where Australia quickly became a world leader (Orchiston \& Slee, 2017; Sullivan, 2017). Before the founding of the Commonwealth Solar Observatory in 1924 (Bhathal et al., 2013), Australian professional astronomy was steeped in positional astronomy, thanks largely to the over-ambitious Astrographic Catalogue and Carte du Ciel project (Débarbat et al., 1988; Turner, 1912). Although Robert Ellery (1827-1908) (Gascoigne, 1992) and Pietro Baracchi (1851-1926) (Orchiston, 2017) at Melbourne Observatory and Henry Russell (18361907) (Bhathal, 1991; Orchiston, 2017) at Sydney Observatory did dabble in astrophysics during the 1880s (for details, see Orchiston et al., 2017), most observational astronomy at the colonial and, from 1900, the state observatories was positional (Haynes et al., 1996). This made it relatively easy for the ATP syndrome to operate: Ellery and Edward John White (1831-1913) (Orchiston, 2017) in Melbourne; Robert Innes (1861-1933) (Orchiston, 
2001, 2003), C. J. Merfield (1866-1931) (Orchiston, 2015) and James Nangle (1868-1941) (Orchiston, 2017) in Sydney; while in 1862, Windsor's John Tebbutt (1834-1916) (Orchiston, 2017) was offered but declined the prestigious Directorship of Sydney Observatory.

Overseas studies of the ATP syndrome in the nineteenth century identify research programs, publications and societal involvement as key characteristics of most of those amateurs who made the transition (Chapman, 1998; Williams, 1988; Ashbrook, 1984; Clerke, 1893); and in cities devoid of professional astronomers, before they became professionals these ATPs often ran their private observatories as de facto city observatories, offering the full range of services and facilities normally available from government- or universityfunded public observatories: public viewing nights; astronomical and meteorological information (particularly through the local media); a local time service; and public lectures, or even courses, on astronomy (Orchiston, 2015).

Moreover, before they became ATPs, in most respects these leading amateur astronomers were behaving as though they were already professional astronomers, even though they were not yet employed as such, and they were viewed by many of their colleagues and interested members of the public as de facto professional astronomers. To all intents and purposes, they were professional astronomers in all but name only! (Orchiston, 2015).

In Australia the story was more complicated, where some of the above factors were irrelevant. Rather, “... timing, the available competition for newly-created positions and an element of good luck, rather than a distinguished international record in astronomy, were sometimes enough to allow one to move along the ATP continuum" (Orchiston, 2015, p. 334). In the case of Robert Ellery, for example, opportunism and political expediency came to the fore: he was the right man in the right place at the right time. Thus, he scored the founding Directorship of Williamstown Observatory in 1853 without having an international record as an amateur astronomer (Orchiston, 2015).

In the case of the Sir Thomas Brisbane Planetarium, it appears that there also was an element of luck and timing involved in the appointment of both Jeff Ryder and Mark Rigby. They too were the right people, in the right place at the right time, yet although each had built a local reputation in amateur astronomy, neither had a major international profile. Nor did they have university training in astronomy, even though this was available at the time in Brisbane. As Haynes et al. (1996) have documented, it was only in the 1960s that Australian universities began to offer undergraduate and postgraduate programs in astronomy. Queensland joined this movement very early when the theoretician Donald Mugglestone transferred to the Department of Physics at The University of Queensland in 1958, and Keith Jones joined the Department in 1963.

By the time Ryder and Rigby went to work at the Sir Thomas Brisbane Planetarium, there were already undergraduate courses in astronomy on offer at The University of Queensland, not to mention graduate research programs on edge-on and active spiral galaxies and the variability of active stars (Haynes et al., 1996). It is telling that neither Ryder nor Rigby saw fit to bolster their amateur astronomy backgrounds with degrees in astronomy, although Rigby had started a BSc degree but changed to a BA that included journalism because of his developing passion for communication that started as early as primary school. Their employer, the Brisbane City Council, did not require formal astronomical qualifications, which could have been obtained through part-time studies, for promotions or to successfully negotiate salary bars. As such, Jeff Ryder and Mark Rigby remain interesting examples of amateur astronomers who were able to make the transition to professional ranks in the second half of the twentieth century.

Thus, the ATP syndrome was still alive and well in Australia at this time, but the fact that it related in these two instances to appointments at a planetarium, rather than a professional observatory or a university astronomy (or physics) department, should not be overlooked. Planetariums were rare in Australia prior to the 1980s, and those employed at this time in Sydney, Melbourne and Brisbane lacked formal training in astronomy, although Dr Con Tenukest, an astronomer at what would later become the University of New South Wales, was actively involved in preparing programs for the planetarium in Sydney during the 1950s and 
1960s (see Orchiston, 1990). It was only later, with the appointment of Glen Moore in Wollongong, Robin Hirst in Melbourne and Martin George in Launceston, that people with formal training in astronomy were appointed to head these planetariums.

\section{Conclusion}

In the absence of a strong tradition in professional astronomy, Brisbane developed a vibrant amateur astronomical community, dating from the 1890s. However, as so often happens in amateur societies, personalities, politics and deaths intervened. These resulted in the demise of the moribund original society (1917), followed by the formation of a short-lived society (from 1919). Then in 1927 a new astronomical society was formed that lasted over 50 years. As outlined, events in 1966 caused internal dissatisfaction, and in 1969 a separate observational and research-oriented society was formed attracting many active members. In 1978, after only nine years, these two bodies amalgamated to form the present Astronomical Association of Queensland.

It was against this backdrop of amateur astronomical activity that initiatives began in 1954 to establish a local planetarium, which culminated in 1978 with the opening of the Sir Thomas Brisbane Planetarium. Initially, the astronomical societies were involved in these plans, specifically in 1966, but their focus was more towards a society observatory and meeting rooms, with a planetarium only a consideration if funds were available. However, it was a daunting task given the makeup and demographics of the membership and was never seriously attempted. In the end, it was the Museum Society and specifically the Brisbane City Council, not the amateur astronomical community, that were responsible for bringing Brisbane its first planetarium.

However, the ASQ and AAQ did contribute in a unique way to the success of the new planetarium by providing the first two Curators, Jeff Ryder and Mark Rigby. Both were accomplished observers and had played leading roles in Brisbane amateur astronomy, and they rank highly within the framework for analysing individual amateur astronomers. Ryder and Rigby also are recent Australian examples of amateur astronomers who turned professional (the ATP syndrome), but we regard them as atypical, given their lack of international visibility when they joined the staff of the Planetarium and the fact that they lacked formal academic training in astronomy. Yet we see this as a feature of the early appointments made to planetariums in Australia.

The cases of Ryder and Rigby illustrate the need to revise the ATP concept as it applies to twentiethcentury amateur astronomers and planetarium appointments. In the nineteenth and early twentieth centuries, most ATPs were involved in astronomical research as amateurs, and continued these commitments when they joined the ranks of professional astronomers. However, the nature of professional astronomy has changed dramatically since the founding of the International Astronomical Union (IAU) in 1919 (Andersen et al., 2019; Sterken et al., 2019), and in addition to astrophysicists also accommodates those involved in designing, developing and building astronomical instrumentation; in researching the history of astronomy, archaeoastronomy and ethnoastronomy (collectively referred to as 'cultural astronomy'); and in conducting education and outreach activities. Thanks largely to the IAU, all of these are now regarded as legitimate areas of professional astronomy.

Planetariums are primarily involved in education and outreach, but not all planetarium professionals - and especially ATPs - conduct research into the effectiveness of different teaching methods, or the range of programs that they offer. Indeed, some planetarians do not even bother to document changes that take place in their planetariums: new instrumentation, new shows, new displays, and new planetarium-related school programs geared to designated curriculum needs, etc. We need to recognise that unlike those ATPs who make the transition to astrophysics, many of those amateur astronomers who come to professional astronomy education positions often will not engage in any form of astronomical research. This is unlike ATPs involved in instrumentation development or cultural astronomy who typically remain research active.

Following their Planetarium appointments, both Ryder and Rigby felt it politic to distance themselves personally from the Brisbane amateur astronomical fraternity, while at the same time 
offering special services to the AAQ. Thus, from time to time they arranged presentations for Society members, and from 2001 to 2009 the monthly meetings were held in the Planetarium's small lecture theatre. But with Mark Rigby taking leave from 1 March 2021 pending retirement (Figure 10), has the 43-year link (1978-2021) between the Sir Thomas Brisbane Planetarium, the AAQ and the amateur astronomers of Brisbane finally come to an end? Only time will tell.

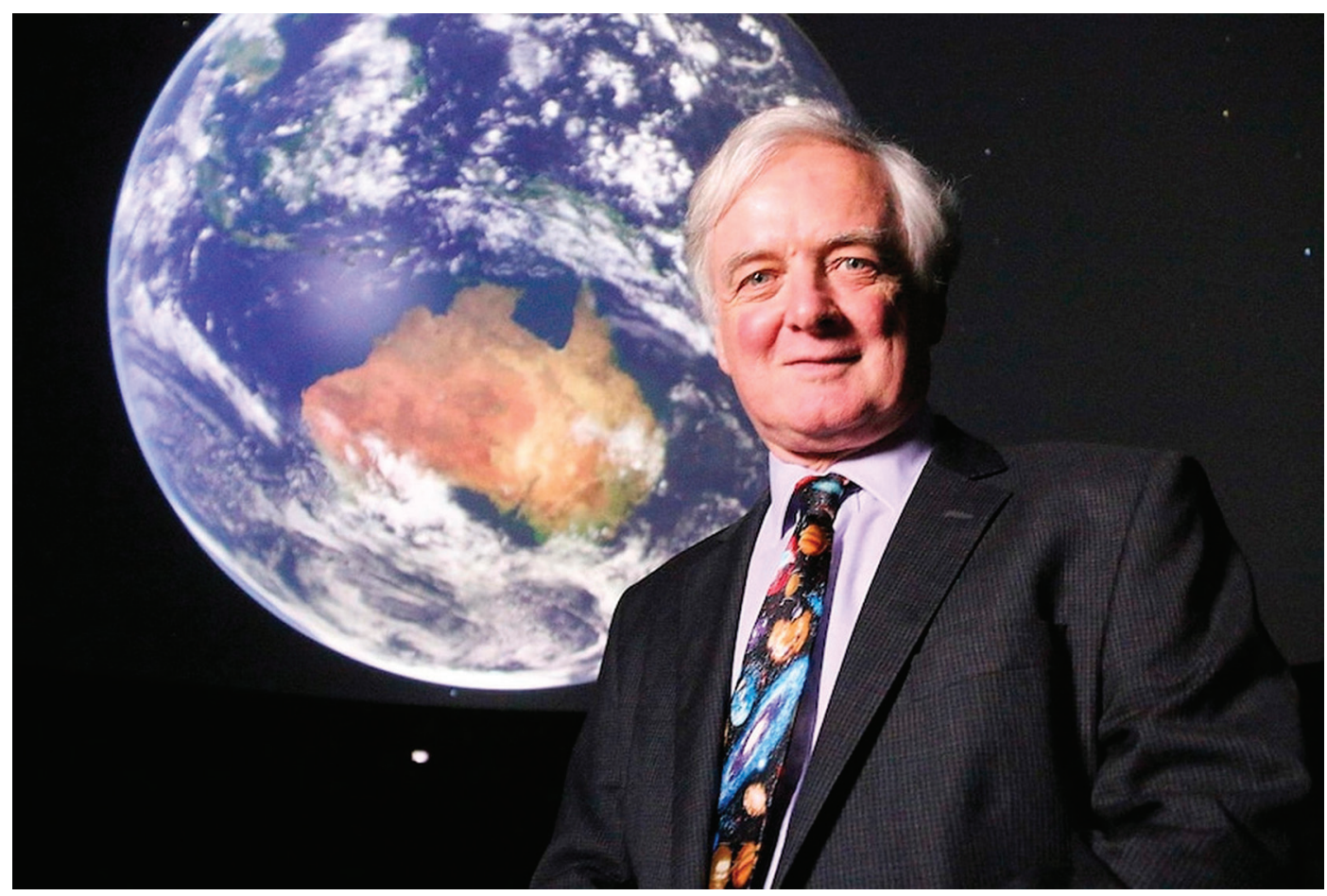

FIGURE 10. Mark Rigby during his retirement interview on 3 March 2021 (Photo courtesy of ABC Online News).

\section{Acknowledgements}

We particularly appreciate the assistance of the retiring Curator of the Sir Thomas Brisbane Planetarium, Mark Rigby, for providing information and Figures 7 and 9 for this paper. We also wish to thank Dr Martin George (formerly Queen Victoria Museum and Art Gallery, Launceston), Dr Andrew Jacob (Sydney Observatory) and Dr Toner Stevenson (University of Sydney) for information about Sydney's first planetarium; Dr Robin Hirst (formerly Science Museum of Victoria) and Dr Warik Lawrance (Museums Victoria) for information about Melbourne's first planetarium; Paul Curnow (University of South Australia) for information about the Adelaide Planetarium; and Dr Martin George for providing details of the founding and early history of the Launceston Planetarium and advice on the portable planetarium phenomenon. We appreciate the assistance provided by Meg Kavanagh, Collection Manager, Museum of Brisbane, Brisbane City Council, for providing permission to reproduce the portrait of Sir Thomas Brisbane (Figure 3), and Brisbane Images, Brisbane City Council, for Figures 4 and 5. Appreciation is also extended to ABC Online News for the use of the image in Figure 10. 


\section{Literature Cited}

Andersen, J., Baneke, D., \& Madsen, C. (2019). The International Astronomical Union: Uniting the Community for 100 Years. Springer. https://doi.org/10.1007/978-3-319-96965-7

Anderson, P. (2019). Brisbane's famous early astronomer - Captain Henry O'Reilly. Proceedings of The Royal Society of Queensland, 124, 99-119.

Anderson, P. E., \& Orchiston, W. (2020). The Brisbane Astronomical Society (1896 to 1917), its six-inch refractor, and key members Dudley Eglinton and James Park Thomson. Proceedings of The Royal Society of Queensland, 128, 143-166.

Anon. (1950, 17 December). Star-gazers get 'time machine'. The Sunday Telegraph [Sydney], p. 10.

Anon. (1954, 13 December). Why not build a PLANETARIUM in Brisbane? Brisbane Telegraph, p. 17.

Ashbrook, J. (1984). The astronomical scrapbook: Skywatchers, pioneers, and seekers in astronomy. Sky Publishing Corporation.

Axam, A., Rigby, M., \& Orchiston, W. (2006, 16-24 August). Astronomy, the Australian school curriculum, and the role of the Sir Thomas Brisbane Planetarium [Conference poster]. XXVIth International Astronomical Union General Assembly, Prague (Czech Republic), Commission 46 (Astronomy Education \& Development) Program, SPS2 Meeting.

Baracchi, P. (1914). Astronomy and geodesy in Australia. In G. H. Knibbs (Ed.), Federal handbook prepared in connection with the eighty-fourth meeting of the British Association for the Advancement of Science held in Australia, August 1914 (pp. 326-390). Government Printer.

Beaglehole, J. C. (Ed.). (1963). The Endeavour journal of Joseph Banks. Two Volumes (2nd ed.). Angus and Robertson.

Beaglehole, J. C. (Ed.). (1968). The journals of Captain James Cook on his voyages of discovery. I. The voyage of Endeavour 1768-1771. Cambridge University Press.

Beaglehole, J. C. (1974). The life of Captain James Cook. Hakluyt Society.

Bhathal, R. (1991). Henry Chamberlain Russell-astronomer, meteorologist and scientific entrepreneur. Journal and Proceedings of the Royal Society of New South Wales, 124, 1-21.

Bhathal, R., Sutherland, R., \& Butcher, H. (2013). Mt Stromlo Observatory: From bush observatory to the Nobel Prize. CSIRO Publishing. https://doi.org/10.1071/9781486300761

Cavill, A. R. (1968). Melbourne's H.V. McKay Planetarium. Journal of the Astronomical Society of Victoria, 21, 95-100.

Chapman, A. (1998). The Victorian amateur astronomer. Independent astronomical research in Britain 1820-1920. Wiley.

Clerke, A. (1893). A popular history of astronomy during the nineteenth century. Adam and Charles Black.

Clerke, A. (1903). Problems in astrophysics. Adam and Charles Black.

Creighton, J., \& DeVasto, D. (2019). Illuminating our audiences: Exploring what engages and confuses them. The Planetarian, 48(3), 20-22, 36.

Daut, M. (2020). Fulldome storytelling: Embracing the dome's uniqueness. The Planetarian, 49(2), 12-14, $16,37$.

Débarbat, S., Eddy, J. A., Eichhorn, H. K., \& Upgren, A. R. (Eds.). (1988). Mapping the sky. Past heritage and future directions. Kluwer (Proceedings of IAU Symposium 133).

Dunlop, S., \& Gerbaldi, M., (Eds.). (1988). Stargazers: The contribution of amateurs to astronomy. Springer-Verlag.

Fuller, R. S., Norris, R. P., \& Trudgett, M. (2014a). The astronomy of the Kamilaroi and Euahlayi peoples and their neighbours. Australian Aboriginal Studies, 2014(2), 3-27.

Fuller, R. S., Anderson, M. G., Norris, R. P., \& Trudgett, M. (2014b). The emu sky knowledge of the Kamilaroi and Euahlayi peoples. Journal of Astronomical History and Heritage, 17(2), 171-179.

Fuller, R. S., Trudgett, M., Norris, R.P., \& Anderson, M. G. (2014c). Star maps and travelling to ceremonies: The Euahlayi people and their use of the night sky. Journal of Astronomical History and Heritage, 17(2), 149-160. 
Gascoigne, S. C. B. (1992). Robert L.J. Ellery, his life and times. Proceedings of the Astronomical Society of Australia, 10, 170-176. https://doi.org/10.1017/s1323358000019524

George, M. (2021). Timeline of the Launceston Planetarium. Manuscript (Orchiston Collection).

Haynes, R. D., Haynes, R. A., \& Kitson, W. S. (1993). The history of astronomy in Queensland. Vistas in Astronomy, 36, 231-252. https://doi.org/10.1016/0083-6656(93)90131-3

Haynes, R., Haynes, R., Malin, D., \& McGee, R. (1996). Explorers of the southern sky: A history of Australian astronomy. Cambridge University Press.

Hetherington, N. S. (1976). Amateur versus professional. The British Astronomical Association and the controversy over canals on Mars. Journal of the British Astronomical Association, 86, 303-308.

Hirst, R. (2002). The Planetarium. In C. Rasmussen (Ed.), A museum for the people: A history of Museum Victoria and its predecessors 1854-2000 (pp. 265-267). Scribe Publications.

Jacob, A. (2010). The old Harris Street Spitz Planetarium. Museum of Applied Arts and Sciences, Sydney. https://maas.museum/observations/2010/07/02/the-old-harris-street-spitz-planetarium

King, H. C., \& Millburn, J. R. (1978). Geared to the stars: The evolution of planetariums, orreries, and astronomical clocks. University of Toronto Press.

Langley, S. P. (1884). The new astronomy. Houghton Mifflin.

Lankford, J. (1979). Amateur versus professional: The transatlantic debate over the measurement of Jovian longitude. Journal of the British Astronomical Association, 89, 574-582.

Lankford, J. (1981a). Amateurs and astrophysics: A neglected aspect in the development of a scientific speciality. Social Studies in Science, 11, 275-303. https://doi.org/10.1177/030631278101100301

Lankford, J. (1981b). Amateurs versus professionals: The controversy over telescope size in late Victorian science. Isis, 72, 11-28. https://doi.org/10.1086/352648

Letchford, R. R., White, G. L., \& Ernest, A. D. (2017). The Southern double stars of Carl Rümker I: History, identification, accuracy. Journal of Double Star Observations, 13(2), 220-232.

Lomb, N. (2004). The instruments from the Parramatta Observatory. Historical Records of Australian Science, 15, 211-222. https://doi.org/10.1071/hr04004

Lomb, N. (2015). How astronomers focussed the scope of their discussions: The formation of the Astronomical Society of Australia. Historical Records of Australian Science, 26(2), 36-57. https://doi. org $/ 10.1071 / \mathrm{hr} 14030$

Marché III, J. D. (2005). Theaters of time and space: American planetaria, 1930-1970. Rutgers University Press.

Mobberley, M. (2015). Return to the far side of planet Moore! Rambling through observations, friendships and antics of Sir Patrick Moore. Springer. https://doi.org/10.1007/978-3-319-15780-1

Moore, G. (2020). More than just a life in planetariums: a passion for public engagement. The Planetarian, 49(3), 12-13, 18.

Morrison, Low, A. D. (2004). The soldier-astronomer in Scotland: Thomas Makdougall Brisbane's scientific work in the Northern Hemisphere. Historical Records of Australian Science, 15, 151-176. https://doi.org/10.1071/hr04008

Nakamura, T., \& Orchiston, W. (2017). Introduction. In Nakamura, T., \& Orchiston, W. (Eds.), The emergence of astrophysics in Asia: Opening a new window on the Universe (pp. 1-22). Springer. https://doi.org/10.1007/978-3-319-62082-4_1

Newell, W .J. (1966). ASQ Synopsis, O.G.M. 11 February 1966. Astroquest, 20, 17-18.

Newell, W. J. (1969). 42nd annual report of the Astronomical Society of Queensland. Astroquest, 23, $55-58$.

Norris, R. P. (2016). Dawes Review 5: Australian Aboriginal astronomy and navigation. Publication of the Astronomical Society of Australia, 33, 1-39. https://doi.org/10.1017/pasa.2016.25

Orchiston, W. (1985). Life-history of a telescope: The 17.8-cm refractor at the Riverview Observatory in Sydney. Australian Journal of Astronomy, 1, 57-80. 
Orchiston, W. (1990). The end of an era: Dr Con Tenukest and amateur astronomy in Australia. Australian Journal of Astronomy, 3, 145-155.

Orchiston, W. (1991). Amateur-professional co-operation in astronomy education: A nineteenth century Australian model. Proceedings of the Astronomical Society of Australia, 9, 186-188. https://doi. org/10.1017/s1323358000025546

Orchiston, W. (1997). The role of the amateur in popularising astronomy: An Australian case study. Australian Journal of Astronomy, 7, 33- 66.

Orchiston, W. (1998). Amateur-professional collaboration in Australian science: The earliest astronomical groups and societies. Historical Records of Australian Science, 12, 163-182. https://doi.org/10.1071/ hr9981220163

Orchiston, W. (1999). Comets and communication: amateur-professional tension in Australian astronomy. Publications of the Astronomical Society of Australia, 16, 212-221. https://doi.org/10.1071/as99212

Orchiston, W. (2001). From amateur astronomer to observatory director: The curious case of R.T.A. Innes. Publications of the Astronomical Society of Australia, 18, 317-328. https://doi.org/10.1071/as01036

Orchiston, W. (2003). Passion and patronage: The Afro-Australian astronomy of Robert Thorburn Ayton Innes. Monthly Notices of the Astronomical Society of Southern Africa, 62, 4-13.

Orchiston, W. (2015). The amateur-turned-professional (ATP) syndrome: Two Australian case studies. In W. Orchiston, D. Green, \& R. Strom (Eds.), New insights from recent studies in historical astronomy: Following in the footsteps of F. Richard Stephenson (pp. 259-350). Springer. https://doi. org/10.1007/978-3-319-07614-0_17

Orchiston, W. (2016). Exploring the history of New Zealand astronomy: Trials, tribulations, telescopes and transits. Springer. https://doi.org/10.1007/978-3-319-22566-1

Orchiston, W. (2017). John Tebbutt: Rebuilding and strengthening the foundations of Australian astronomy. Springer. https://doi.org/10.1007/978-3-319-44521-2

Orchiston, W., \& Slee, B. (2017). The early development of Australian radio astronomy: The role of the CSIRO Division of Radiophysics field stations. In Nakamura, T., \& Orchiston, W. (Eds.), The emergence of astrophysics in Asia: Opening a new window on the Universe (pp. 497-578). Springer. https://doi.org/10.1007/978-3-319-62082-4_19

Orchiston, W., Clark, B. A. J., Frew, D., \& Andropoulos, J. (2017). The development of astronomy and the foundation of astrophysics in Australia. In Nakamura, T., \& Orchiston, W. (Eds.), The emergence of astrophysics in Asia: Opening a new window on the Universe (pp. 395-452). Springer. https://doi. org/10.1007/978-3-319-62082-4_17

Orchiston, W., \& Darlington, V. (2017). A tale of two telescopes: North Queensland and the 1882 transit of Venus. Journal of Astronomical History and Heritage, 20, 223-253.

Plummer, J. D., \& Small, K. J. (2018). Using a planetarium fieldtrip to engage young children in threedimensional learning through representations, patterns and lunar phenomena. International Journal of Science Education, Part B, 8(3), 193-212. https://doi.org/10.1080/21548455.2018.1438683

Richardson, W. (1835). Catalogue of 7385 stars, chiefly in the Southern Hemisphere, prepared from observations made in the years 1822, 1823, 1824, 1825, and 1826, at the observatory at Paramatta [sic], New South Wales ... His Majesty's Stationery Office.

Rothenberg, M. (1981). Organisation and control: professionals and amateurs in American astronomy, 1899-1918. Social Studies in Science, 11, 305-325. https://doi.org/10.1177/030631278101100302

Ryder, J. (1979). The Sir Thomas Brisbane Planetarium. Sky \& Telescope, 58, 217.

Ryder, J. W. (1984). Australiens erstes modernes planetarium - das Sir Thomas Brisbane Planetarium. Jenaer Rundschreiben, 29(3), 146-148.

Saunders, S. (2004). Sir Thomas Brisbane's legacy to colonial science: colonial astronomy at the Parramatta Observatory, 1822-1848. Historical Records of Australian Science, 15, 177-209. https:// doi.org/10.1071/hr04009 
Stebbins, R. A. (1977). The amateur: Two sociological definitions. Pacific Sociological Review, 20, $582-$ 606. https://doi.org/10.2307/1388717

Stebbins, R. A. (1978). Towards amateur sociology: A proposal for the profession. The American Sociologist, 13, 239-252.

Stebbins, R. A. (1979). Amateurs: On the margin between work and leisure. Sage Publications.

Stebbins, R. A. (1980a). "Amateur" and "hobbyist" as concepts for the study of leisure problems. Social Problems, 27, 413-417. https://doi.org/10.1525/sp.1980.27.4.03a00040

Stebbins, R. A. (1980b). Avocational science: The amateur routine in archaeology and astronomy. International Journal of Comparative Sociology, 21,34-48. https://doi.org/10.1163/156854280x00038

Stebbins, R. A. (1981). Science amators? Rewards and cost in amateur astronomy and archaeology. Journal of Leisure Research, 13, 289-304. https://doi.org/10.1080/00222216.1981.11969494

Stebbins, R. A. (1982a). Amateur and professional astronomers: A study of their interrelationships. Urban Life, 10, 433-454. https://doi.org/10.1177/089124168201000404

Stebbins, R. A. (1982b). Looking downwards: Sociological images of the vocation and avocation of astronomy. Southern Stars, 29, 177-188.

Stebbins, R. A. (1987). Amateurs and their place in professional science. In D. S. Hayes, R. M. Genet, \& D. R. Genet (Eds.), New generation small telescopes (pp. 217-225). Fairborn Press.

Stebbins, R. A. (1992). Amateurs, professionals, and serious leisure. McGill-Queens University Press.

Sterken, C., Hearnshaw, J., \& Valls-Gabaud, D. (Eds.). (2019). Under one sky: The IAU centenary symposium. Cambridge University Press.

Sullivan III, W. T. (2017). The beginnings of Australian radio astronomy. In Nakamura, T., \& Orchiston, W. (Eds.), The emergence of astrophysics in Asia: Opening a new window on the Universe (pp. 453-496). Springer. https://doi.org/10.1007/978-3-319-62082-4_18

Turner, H. H. (1912). The Great Star Map: Being a brief general account of the international project known as the Astrographic Chart. Murray.

Vahia, M. N., \& Halkare, G. (2013). Aspects of Gond astronomy. Journal of Astronomical History and Heritage, 16(1), 29-44.

Williams, T. (1988). A galaxy of amateur astronomers. Sky \& Telescope, 76(5), 484-486.

Williams, T. R. (2000). Getting organized: A history of amateur astronomy in the United States [Doctoral dissertation, Rice University]. http://hdl.handle.net/1911/19569

Yu, K. C., Sahami, K., \& Dove, J. (2017). Learning about the scale of the Solar System using digital planetarium visualisations. American Journal of Physics, 85(7), 550-556. https://doi.org/10.1119/ 1.4984812

\section{Author Profiles}

Peter Anderson has been President of the Astronomical Association of Queensland and its predecessors on five occasions since 1966. In addition to active participation in astronomical tourism, especially to observe total solar eclipses, Peter has been a guest lecturer on cruise ships for nine years presenting astronomical topics. He has also written many articles and is an active contributor in the field. For the last 40 years he has conducted astronomical research from his observatory at The Gap, Brisbane, specialising in the field of lunar and asteroidal occultation of stars. Peter also maintains a strong interest in the history of Queensland astronomy.

Professor Wayne Orchiston is affiliated with the Centre for Astrophysics at the University of Southern Queensland. A former amateur astronomer and President of the BAA (NSW Branch) and the Astronomical Society of Victoria, he has published extensively on Australian astronomy, including a book about John Tebbutt. He has also published on aspects of Chinese, English, French, German, Indian, Indonesian, Japanese, New Zealand, Philippines, South Korean, Thai and US astronomical history. Currently he is Immediate Past President of IAU Commission C3 (History of Astronomy), and Minor Planet '48471 Orchiston' has been named after him. 